Der Artikel ist im Verlag DE GRUYTER erschienen und unter

https://www.degruyter.com/view/j/znb.2013.68.issue-10/znb.2013-3196/znb.2013-3196.xml erhältlich.

Die Verlagsveröffentlichung ist verfügbar unter www.degruyter.com. 


\section{Surface-active Ionic Liquids for Micellar Extraction of Piperine from Black Pepper}

Anna K. Ressmann ${ }^{\mathrm{a}}$, Ronald Zirbs ${ }^{\mathrm{b}}$, Martin Pressler ${ }^{\mathrm{a}}$, Peter Gaertner ${ }^{\mathrm{a}}$, Katharina Bica ${ }^{\mathrm{a}}$

${ }^{a}$ Institute of Applied Synthetic Chemistry, Vienna University of Technology, 1060 Vienna, Austria ${ }^{b}$ Group for Biologically Inspired Materials, Institute of Nanobiotechnology (DNBT), University of Natural Resources and Life Sciences, Muthgasse 11, 1190 Vienna, Austria

Reprint requests to Dr. Katharina Bica. Fax +43 158801 16399. E-mail:

katharina.bica@tuwien.ac.at

Z. Naturforsch. 2013, 68b, XXXX-XXXX; received

We present the application of ionic liquid-aqueous micellar solutions as isolation media for the pharmaceutically active ingredient piperine from black pepper. Several surface-active ionic liquids including a biodegradable betaine-derivative were used for the extraction of piperine, and a strong correlation between extraction yield and the critical micelle concentration of the respective ionic liquid was found. A scaled strategy for the isolation of piperine was developed that allowed recovery and recycling of the aqueous ionic liquid micellar solution for five runs without any loss in extraction efficiency.

Key words: Ionic Liquids, Micelles, Active Ingredient Isolation, Piperine, Biomass Processing, Sustainable Chemistry 


\section{Introduction}

Biomass feedstocks provide a unique and indispensible source for drug development and manufacturing: Current estimations of the pharmaceutical market indicate that approximately a third of all drugs currently on the market is derived from natural products.[1] Piperine $((2 E, 4 E)-$, 5-(1,3-benzodioxol-5-yl)-1-(1-piperidinyl)-, 2,4-pentadien-1-one, 1), a common alkaloid that is responsible for the pungent taste of pepper, is naturally occurring in Piper nigrum (6-9\%), in Piper longum fruits (4\%) and in Piper retrofractum (4-5\%).[2] Apart from its nutraceutical uses, it has attracted attention for its inhibitory influence on enzymatic drug biotransforming reactions in the liver. The pharmacological properties of piperine are widespread: Piperine exhibites not only antifungal[3], antidiarrhoeal[4], anti-inflammatory[5], 5-lipoxygenase and cyclooxygenase-1 inhibitory activities[6], but serves as a positive $\mathrm{GABA}_{\mathrm{A}}$ receptor.[7-8]

As most plant-derived active ingredients, piperine is typically isolated from cultivated plant material using excessive refluxing with volatile organic solvents such as ethanol, toluene or chlorinated hydrocarbons.[9]'[10] This extraction process is not only time consuming and requires waste amounts of often toxic solvents, but suffers from co-extraction of undesired by-products such as gums, polysaccharides or essential oils. Additional purification steps are thus required making the isolation and purification of a natural product a large obstacle in any cost-efficient and sustainable drug manufacturing process.

In the past years, ionic liquids (ILs, salts with melting point $<100{ }^{\circ} \mathrm{C}$ ) have emerged as alternative solvents for biomass processing, as they provide unique dissolution properties for biomass feedstocks. Based on the disruption of the intermolecular hydrogen-bonded network up to $\sim 30$ wt.- $\%$ cellulose can be solubilized in ionic liquids that are typically composed of imidazolium head groups. This can be highly beneficial for the extraction of valuable ingredients from biomass, as the tunability of ionic liquids allows designing a tailor-made 
ionic liquid for a specific extraction problem. While the use of ionic liquids for biomass dissolution such as wood[11-15], cellulose[16-19], lignin[20], chitin[21-24], silk fibroin[25], wool keratin[26], starch and zein protein[27], cotton and bamboo[28], chitosan[21] and cork biopolymers, [29] has attracted tremendous interest, fewer attention has been paid to the isolation of valuable ingredients using ionic liquids. Pioneering work was performed by Lapkin et al. in a study comparing conventional solvents, ionic liquids, supercritical carbon dioxide and fluorous solvents for the extraction of the antimalaria drug artemisinin from crude Artemisia annua seeds.[30] In the past years this strategy has spread, and successful examples for the application of ionic liquids as extraction media include the isolation of the pharmaceutically active steroid betulin from birch bark[31], suberinic material from cork[32], the bioactive alkaloid $S$-(+)-glaucine from plant material of Glaucium flavum Crantz (Papaveraceae)[33-34], the flavonoid rutin[35], and the actives senkyunolide I, senkyunolide $\mathrm{H}$ and Z-ligustide[36], or shikonin and $\beta, \beta^{\prime}$-dimethylacrylshikonin[37] from traditional Chinese medical plants. Additionally, valuable essential oils, e. g. orange oil or rosmary oil could be directly distilled from the ionic liquid media, thus allowing a simple isolation of the pure volatile fragrance components and a complete recovery of the ionic liquid.[38-40] An elegant strategy was also developed by the group of MacFarlane, who used a distillable ionic media for the isolation of hydrolysable tannins[41]. In some cases, the role of the ionic liquid is not limited to the use as mere solvent, but can directly take part in the further transformation towards a drug intermediate, as we could previously show for the reactive dissolution of star anise with Brønsted-acidic ILs that gave direct access to an important intermediate for the manufacturing of the anti-influenza drug Tamiflu $^{\mathrm{TM}}$.[42]

While ionic liquids often proved to be superior to conventional solvents in terms of extraction yield and purity, their usage is still associated with a major drawback: Ionic liquids are still relatively expensive - at least compared to conventional organic solvents - which 
may restrict their large-scale application as a bulk solvent. Our search for a compromise between economic and environmental criteria got us interested in the use of aqueous-ionic liquid systems as reaction media for synthesis and catalysis.[43] Recent investigations on the behavior of ionic liquids in the presence of water showed that certain ionic liquids can form aggregates in aqueous solution.[44-47] This is the case for long-chain 1-alkyl-3methylimidazolium chloride salts $\left[\mathrm{C}_{n} \mathrm{mim}\right] \mathrm{Cl}$ with $n=8-18$, where the apolar side chain stays in contact with other cations and micelles are formed. While the physico-chemical properties of 1-alkyl-3-methylimidazolium chlorides and bromides are reasonably well explored so that critical micelle concentration values (CMC) are available, applications remain limited. Yet we could show that these micellar systems can be efficiently applied for synthesis and found enhanced reaction rates for Diels-Alder reaction compared to neat water. A similar effect was reported by Coutinho et al., who found increased enzyme activity of Candida antarctica lipase B (CaLB), in aqueous solutions of the ionic liquid 1-decyl-3methylimidazolium chloride $\left[\mathrm{C}_{10} \mathrm{mim}\right] \mathrm{Cl}$.[48]

The concept of aqueous-ionic liquid systems as extraction media has been only sparingly explored, although promising work on the cellulose pretreatment with aqueous solutions of ionic liquids has been reported by Welton et al.[49] Cao et al. investigated IL ultrasound assisted extraction for the isolation of piperine from white pepper.[50] Different aqueous solutions of short-chain 1-alkyl-3-methylimidazolium bromide $\left[\mathrm{C}_{n} \operatorname{mim}\right] \mathrm{Br}$ with $n=3$ and $n$ $=4$ were used in rather high concentration of $5 \mathrm{M}$. A strong influence on the anion was observed, as the extraction efficiency decreased in the order $\mathrm{BF}_{4}^{-}>\mathrm{Br}^{-}>\mathrm{H}_{2} \mathrm{PO}_{4}^{-}>\mathrm{PF}_{6}^{-}$ which was explained by a reduced hydrophilicity and water miscibility. ${ }^{[50]}$ Although $\left[\mathrm{C}_{4} \mathrm{mim}\right] \mathrm{Br}$ performed significantly better than $\left[\mathrm{C}_{3} \mathrm{mim}\right] \mathrm{Br}$, longer chain lengths of the alkyl imidazolium backbone were not investigated. Recently Coutinho et al. published an elegant strategy for the isolation of caffeine from guaraná seeds using aqueous IL solutions.[51] 
Only few papers explore the extraction of active ingredients with surface-active ionic liquids. Yao et al. extracted different tanshinones, namely tanshinone I, tanshinone IIA and cryptotanshinone from Salvia miltiorrhiza bunge. Based on bromide anions, the chain length of 1-alkyl-3-methylimdazolium cation was varied, as tanshinones are lipophilic compounds. While $\left[\mathrm{C}_{8} \mathrm{mim}\right] \mathrm{Br}$ failed to extract the active ingredients, the extraction yield increased dramatically for tanshinone I and tanshinone IIA when the chain length was increasing from $\mathrm{C}_{10}$ to $\mathrm{C}_{16 .}$ [52] Microwave assisted micellar extraction was also successfully applied by Lin $e t$ al. in 2012 using an aqueous two-phase system (ATPS) system consisting of $\left[\mathrm{C}_{n} \mathrm{mim}\right] \mathrm{BF}_{4} / \mathrm{NaH}_{2} \mathrm{PO}_{4}$ for the active ingredients hyperin and isoquercitrin from Apocynum venetum; however, better results were obtained with the butyl chain length rather than with the surface-active 1-methyl-3-octylimidazolium tetrafluoroborate.[53]

In this paper, we suggest that IL-water micellar systems might provide a novel and efficient but yet cost-efficient extraction media for active ingredients. Based on the extraction of piperine from ground black pepper, we investigate micellar solutions of several surfaceactive ionic liquids as extraction media and provide a scaled strategy for the isolation of piperine allowing recovery and recycling of the aqueous-ionic liquid micellar solution.

\section{Results and Discussion}

We have chosen a set of surface-active ionic liquids based on common 1-alkyl-3methylimidazolium chlorides $\left[\mathrm{C}_{n} \operatorname{mim}\right] \mathrm{Cl} \mathbf{2}, \mathbf{3}$ and $\mathbf{8}$ with alkyl chain length varying from $n=$ 10 to $n=14$. As the inherent toxicity and biodegradability of long-chain imidazolium salts might restrict their application, we also included a surface-active betaine-derived ionic liquid 9 that has been reported to be biodegradable. (Fig. 1) 
In an initial screening, we developed an HPLC strategy that allowed quantifying piperine in the presence of the aqueous ionic liquid systems to quickly identify optimum conditions for the extraction process. When investigating the influence of extraction time using a $50 \mathrm{~mm}$ $\left[\mathrm{C}_{12} \mathrm{mim}\right] \mathrm{Cl}$ solution in water at $25{ }^{\circ} \mathrm{C}$, we found that with increasing extraction time, extraction efficiency also increased (Table 1, entries 1-3). As a compromise between time demand and extraction yield, we decided to work with an extraction time of 3 hours as already 3.74 wt.- $\%$ of piperine per black pepper dry weight have been extracted in that time. When the ratio between biomass and ionic liquid solution was further investigated, we found only a slight difference between $1 \%(\mathrm{w} / \mathrm{v})$ and $5 \%(\mathrm{w} / \mathrm{v})$ biomass in ionic liquid containing solution. However, with a higher biomass loading of $10 \%(\mathrm{w} / \mathrm{v})$ the extraction efficiency decreased significantly, which might be related to mixing problems. (Table 1, entries 4-6)

\section{$<$ Table 1>}

Based on the optimum conditions, we turned our attention towards the influence of different concentrations of $\left[\mathrm{C}_{12} \mathrm{mim}\right] \mathrm{Cl}$ in water. We found an interesting correlation of the CMC of the respective ionic liquid with the extraction yield of piperine: At low concentrations of $\leq 10 \mathrm{mM}$, only small amounts of piperine $<0.20 \mathrm{wt} .-\%$ could be extracted, which is only slightly higher than the extraction yield that was obtained with pure water at similar conditions. However, as soon as the concentration of $\left[\mathrm{C}_{12} \mathrm{mim}\right] \mathrm{Cl}$ reached the $\mathrm{CMC}$ (15 mM) a significant increase in the extraction efficiency was observed.[54-56] (Fig. 2)

$<$ Figure 2>

A similar pattern was observed when expanding the range of ionic liquids. For solutions of $\left[\mathrm{C}_{10} \mathrm{mim}\right] \mathrm{Cl}(\mathbf{2}),\left[\mathrm{C}_{14} \mathrm{mim}\right] \mathrm{Cl}(\mathbf{8})$ as well as the biodegradable $\left[\mathrm{C}_{12}\right.$ betaine $] \mathrm{Cl}$ (9) the extraction efficiency dramatically increased at concentrations higher than CMC of the respective ionic liquid. For all ionic liquids, the extraction yield eventually leveled off at 
concentrations higher than $100 \mathrm{mM}$, and up to $\sim 4 \mathrm{wt} .-\%$ of piperine could be extracted. We found that the increase in the extraction efficiency can be correlated with the chain length and found an increase occurring in the order $\left[\mathrm{C}_{14} \mathrm{mim}\right] \mathrm{Cl}(\mathbf{8})<\left[\mathrm{C}_{12} \mathrm{mim}\right] \mathrm{Cl}(\mathbf{3}) \approx\left[\mathrm{C}_{12}\right.$ betaine $] \mathrm{Cl}$ (9) $<\left[\mathrm{C}_{10} \mathrm{mim}\right] \mathrm{Cl}(\mathbf{2})$. This again is in accordance with literature data, as a linear relationship between the logarithm of CMC and the number of carbon atoms $n$ is found for 1-alkyl-3methylimidazolium-based ionic liquids $\left[\mathrm{C}_{n} \mathrm{mim}\right] \mathrm{Cl}$. In comparison to the large effect of the chain length in the cation, the anion in the surface-active ionic liquids $\left[\mathrm{C}_{12} \mathrm{mim}\right] \mathrm{X}$ had less influence on the extraction efficiency. With the exception of the triflate anion (X = OTf, 5) that gave only moderate yields of 2.28 wt.- $\%$, all other anions including halides $\left(\mathrm{X}=\mathrm{Cl}^{-}\right.$or $\left.\mathrm{Br}^{-}, 4\right)$, dicyanamide $\left(\mathrm{X}=\mathrm{N}(\mathrm{CN})^{-}, \mathbf{6}\right)$ or acetate $\left(\mathrm{X}=\mathrm{OAc}^{-}, 7\right)$ were suitable for the extraction and gave comparable yields between 3.20 and 3.74 wt.-\%. (Table 2)

\section{$<$ Table 2>}

When comparing the extraction performance of micellar solutions of 1-alkyl-3methylimidazolium-based ionic liquids, we found that these solutions can compete with different conventional organic solvents reported in literature. The volatile and toxic solvents such as chloroform, methanol and toluene gave only slightly higher yields of $3.81-4.10$ wt.- $\%$, whereas the environmentally more benign butyl acetate extracted around 3.10 wt.-\% and gave the lowest yield among the organic solvents screened here (Fig. 3).

$<$ Figure 3>

The importance of the surface-activity of the applied ionic liquid solution is obvious when the extraction yield is compared with the yield of a $50 \mathrm{~mm}$ solution of $\mathrm{NaCl}$ in water: Only 0.06 wt.- $\%$ could be isolated here, which is even below the extraction yield with pure water, that reached $0.11 \mathrm{wt} .-\%$. The influence of aqueous ionic liquid solutions compared to pure water is also visible from electron microscopy that was performed on the recovered 
biomass after extraction. Although micellar solution of 1-alkyl-3-methylimidazolium based ionic liquids $\left[\mathrm{C}_{n} \mathrm{mim}\right] \mathrm{Cl}$ did not completely dissolve biomass as we observed in our previous studies with neat ionic liquids, we observed some changes in biomass morphology that could not be observed when pure water was used as extraction media (Fig. 4). A similar effect was observed by Coutinho et al. who investigated the extraction of caffeine from guaraná seed and reported an increase in the ratio of broken cells to intact cells in the presence of ionic liquid/aqueous mixtures, although the biomass was not completely dissolved.

$<$ Figure 4>

Consequently, it seems that complete solubilization of the biopolymer matrix is not always necessary for efficient extraction of the valuable ingredients: When comparing the extraction yields of aqueous solution of the ionic liquids $\left[\mathrm{C}_{n} \mathrm{mim}\right] \mathrm{Cl}$ with those obtained with pure ionic liquids, we found that the micellar systems can be a superior alternative to the neat ionic liquid (Table 3, entries 1-3). It should be noted that the extraction with pure ionic liquids had to be performed at $80{ }^{\circ} \mathrm{C}$ as $\left[\mathrm{C}_{12} \mathrm{mim}\right] \mathrm{Cl}$ and $\left[\mathrm{C}_{14} \mathrm{mim}\right] \mathrm{Cl}$ were solid at room temperature. Even at this temperature, viscosity problems occurred with longer alkyl chains and the extraction efficiencies decreased. Only $\left[\mathrm{C}_{10} \mathrm{mim}\right] \mathrm{Cl}$, which is liquid at room temperature gave comparable yields to the aqueous micellar solution.

$<$ Table 3>

\section{Scaled procedure and reusability of the extraction media}

Once the optimum extraction conditions were identified, we turned our attention towards a scaled extraction process allowing not only the isolation of piperine, but also the recovery of the micellar ionic liquid solution (Fig. 5). 
As previously optimized we worked in a $5 \%(\mathrm{w} / \mathrm{v})$ solution of ground black pepper. After extraction of $1.00 \mathrm{~g}$ ground black pepper with $19 \mathrm{~mL}$ of a $50 \mathrm{~mm}$ solution of $\left[\mathrm{C}_{12}\right.$ betaine $] \mathrm{Cl}$ in water for $3 \mathrm{~h}$ at room temperature, the remaining biomass was removed via filtration. Once the biomass was removed, the micellar solution was extracted with a small amount of environmentally benign butyl acetate. We found that after extraction with only 5 $\mathrm{mL}$ butyl acetate piperine was nearly quantitatively separated leaving less than 0.2 wt.-\% piperine in the ionic liquid micellar solution. This allowed not only a quick and clean separation of piperine in excellent purity, but also the recovery of the aqueous solution containing the ionic liquid that could be directly used for four additional runs without any loss in performance (Fig. 6).

$<$ Figure 6>

Alternatively, the micellar solution containing piperine can be directly subjected to any consecutive synthetic modification towards piperine-derivatives, which will be the object of our future studies.

\section{Conclusion}

Aqueous-ionic liquids micellar solutions are an efficient extraction media for the isolation of active ingredients and can overcome issues of conventional organic solvents. Based on the isolation of piperine from black pepper, we demonstrated that the extraction efficiency of various aqueous-ionic liquid micellar solutions strongly depends on the CMC of the respective ionic liquid. Based on a biodegradable betaine derivative, a simple and scalable isolation procedure was developed, and it allowed separation of piperine from the extraction media and the recycling of the aqueous solution for four times without loss in the extraction efficiency. 
Commercially available reagents and solvents were used as received from Sigma Aldrich unless otherwise specified. Ionic liquids $\left[\mathrm{C}_{10} \mathrm{mim}\right] \mathrm{Cl}$, and $\left[\mathrm{C}_{12} \mathrm{mim}\right] \mathrm{Cl}\left[\mathrm{C}_{12} \mathrm{mim}\right] \mathrm{Br}$ and $\left[\mathrm{C}_{14} \mathrm{mim}\right] \mathrm{Cl}$ were prepared from freshly distilled $N$-methylimidazole and alkyl chloride or alkyl bromide according to the literature. Solid $\left[\mathrm{C}_{12} \mathrm{mim}\right] \mathrm{Cl}$ and $\left[\mathrm{C}_{14} \mathrm{mim}\right] \mathrm{Cl}$ were repeatedly crystallized from THF until colorless crystals were obtained. Ionic liquids $\left[\mathrm{C}_{12} \mathrm{mim}\right] \mathrm{OTf}$, $\left[\mathrm{C}_{12} \mathrm{mim}\right] \mathrm{N}(\mathrm{CN})_{2}, \quad\left[\mathrm{C}_{12} \mathrm{mim}\right] \mathrm{OAc}$ have been previously reported in literature and were prepared via metathesis reaction of $\left[\mathrm{C}_{12} \mathrm{mim}\right] \mathrm{Cl}$ with the corresponding silver salt of the anion. All ionic liquids were dried for at least $24-48 \mathrm{~h}$ at $50{ }^{\circ} \mathrm{C}$ and $0.01 \mathrm{mbar}$ before use and were stored under argon.

${ }^{1} \mathrm{H}$ and ${ }^{13} \mathrm{C}$ NMR spectra were recorded on a Bruker AC 400 spectrometer at 400 and $100 \mathrm{MHz}$, resp., using the solvent peak as reference. $J$ values are given in $\mathrm{Hz} .{ }^{13} \mathrm{C}$ NMR spectra were run in proton-decoupled mode.

For the determination of piperine a Phenomenex Luna $10 \mu \mathrm{m}$ C18 100A column $(250 \times$ $4.60 \mathrm{~mm}$ ) was used with $\mathrm{CH}_{3} \mathrm{CN} / \mathrm{H}_{2} \mathrm{O} 55 / 45$ as solvent and a flow of $1 \mathrm{~mL} / \mathrm{min}$; detection was done at $271 \mathrm{~nm}$, at $30{ }^{\circ} \mathrm{C}$ column oven temperature, $4{ }^{\circ} \mathrm{C}$ tray temperature. Retention times were 4.07 min for phenol and 9.2 min for piperine. Standard calibrations were performed for aqueous and organic extraction.

\section{Dodecyl 2-chloroacetate}

Dodecanol (14.18 g, $76.10 \mathrm{mmol})$ and chloroacetyl chloride $(11.17 \mathrm{~g}, 98.90 \mathrm{mmol})$ in 50 were dissolved in $50 \mathrm{~mL}$ of anhydrous dichloromethane under argon and chilled to $0{ }^{\circ} \mathrm{C}$. Triethylamine (10.00 g, $98.90 \mathrm{mmol})$ was added dropwise. The solution was stirred at room temperature over night until TLC indicated full conversion. The solution was diluted with $50 \mathrm{~mL}$ of water and extracted with dichloromethane. The combined organic layers were successively washed with $2 \mathrm{~N} \mathrm{HCl}$, saturated $\mathrm{NaHCO}_{3}$ and brine. The solution was dried over 
$\mathrm{Na}_{2} \mathrm{SO}_{4}$, filtered and evaporated to dryness. Dodecyl 2-chloroacetate was obtained as a light yellow oil in $95 \%$ yield and used as obtained.

${ }^{1} \mathrm{H}$ NMR $\left(\mathrm{CDCl}_{3}\right): \delta=0.88\left(3 \mathrm{H}, \mathrm{t}, J=6.4 \mathrm{~Hz},-\mathrm{C}_{11} \mathrm{H}_{22}-\mathrm{CH}_{3}\right), 1.26\left(18 \mathrm{H}, \mathrm{m},-\mathrm{C}_{2} \mathrm{H}_{4}-\mathrm{C}_{9} H_{18^{-}}\right.$ $\left.\mathrm{CH}_{3}\right), 1.67\left(2 \mathrm{H}, \mathrm{t}, J=6.6 \mathrm{~Hz},-\mathrm{CH}_{2}-\mathrm{CH}_{2}-\mathrm{C}_{10} \mathrm{H}_{21}\right), 4.06\left(2 \mathrm{H}, \mathrm{s}, \mathrm{Cl}-\mathrm{CH}_{2}-\mathrm{CO}\right), 4.19(2 \mathrm{H}, \mathrm{t}, J=$ $\left.0.7 \mathrm{~Hz},-\mathrm{CH}_{2}-\mathrm{C}_{11} \mathrm{H}_{23}\right)$. These data was in accordance with the literature data.[57]

\section{2-(Dodecyloxy)-N,N,N-trimethyl-2-oxoethanaminium chloride, $\left[\mathrm{C}_{12}\right.$ betaine $] \mathrm{Cl}(\mathbf{9})$}

Dodecyl 2-chloroacetate $(5.39 \mathrm{~g}, 20.51 \mathrm{mmol})$ was dissolved in $15 \mathrm{~mL}$ anhydrous THF. A solution of trimethylamine in THF $(102.5 \mathrm{mmol})$ was added dropwise at room temperature. After stirring over night the precipitate was collected via filtration and washed with anhydrous THF and anhydrous diethyl ether. After drying in vacuo (2·10-2 mbar) overnight $\left[\mathrm{C}_{12}\right.$ betaine $] \mathrm{Cl} 9$ was obtained as colorless crystals in $88 \%$ yield.

${ }^{1} \mathrm{H}$ NMR $\left(\mathrm{CDCl}_{3}\right): \delta=0.81\left(3 \mathrm{H}, \mathrm{t}, J=7.0,-\mathrm{C}_{11} \mathrm{H}_{22}-\mathrm{CH}_{3}\right), 1.19\left(18 \mathrm{H}, \mathrm{m},-\mathrm{C}_{2} \mathrm{H}_{4}-\mathrm{C}_{9} H_{18^{-}}\right.$ $\left.\mathrm{CH}_{3}\right), 1.58\left(2 \mathrm{H}, \mathrm{t}, J=6.7,-\mathrm{CH}_{2}-\mathrm{CH}_{2}-\mathrm{C}_{10} \mathrm{H}_{21}\right), 3.60\left(9 \mathrm{H}, \mathrm{s}, \mathrm{N}-\left(\mathrm{CH}_{3}\right)_{3}\right), 4.10(2 \mathrm{H}, \mathrm{t}, J=7.0$, $\left.\mathrm{CH}_{2}-\mathrm{C}_{11} \mathrm{H}_{23}\right), 5.01\left(2 \mathrm{H}, \mathrm{s}, \mathrm{Cl}-\mathrm{CH}_{2}-\mathrm{CO}\right)$ These data was in accordance with literature data.[58]

\section{Extraction procedure for IL solutions}

A suspension of black pepper in aqueous IL solution (1 wt.-\%: $10.0 \mathrm{mg}$ pepper, $990 \mathrm{mg}$ IL solution, 5 wt.-\%: $50 \mathrm{mg}$ pepper, $950 \mathrm{mg}$ IL solution, $10 \mathrm{wt} .-\%$ : $100 \mathrm{mg}$ pepper, $900 \mathrm{mg}$ IL solution) was stirred at $25^{\circ} \mathrm{C}$ for $3 \mathrm{~h}$. A sample of $100 \mu \mathrm{L}$ was taken from the supernatant and diluted to $5 \mathrm{~mL}$ with the IL solution. An aliquot of $1 \mathrm{~mL}$ was taken, mixed with $200 \mu \mathrm{L}$ of internal standard (60.0 mg phenol in $100 \mathrm{~mL}$ of water) filtered over $0.2 \mu \mathrm{m}$ syringe filter and immediately measured. Results are based on three independent experiments. 
Ground black pepper $(1.000 \mathrm{~g})$ was stirred with $19 \mathrm{~mL}$ of a $50 \mathrm{~mm}$ solution of $\left[\mathrm{C}_{12}\right.$ betaine $] \mathrm{Cl}$ in water at $25^{\circ} \mathrm{C}$ for $3 \mathrm{~h}$. After filtration the solution was extracted 3 times with a total volume of $5 \mathrm{~mL}$ of $n$-butyl acetate. Samples of $100 \mu \mathrm{L}$ were taken from the aqueous layer, and HPLC was measured before and after extraction with butyl acetate to quantify the amount of piperine in the micellar solution. The remaining micellar solution was directly used for the next extractions step without further purification.

For isolation of piperine, the combined organic layers were dried over $\mathrm{Na}_{2} \mathrm{SO}_{4}$, filtered and evaporated to dryness.

${ }^{1} \mathrm{H}$ NMR $\left(\mathrm{CDCl}_{3}\right): \delta=1.59-1.63\left(\mathrm{~m}, 6 \mathrm{H}, \mathrm{N}-\mathrm{CH}_{2}-\mathrm{CH}_{2}-\mathrm{CH}_{2}-\mathrm{CH}_{2}-\mathrm{CH}_{2}-\right), 3.54-3.64(\mathrm{~m}$, $\left.4 \mathrm{H}, \mathrm{N}-\mathrm{CH}_{2}-\mathrm{CH}_{2}-\mathrm{CH}_{2}-\mathrm{CH}_{2}-\mathrm{CH}_{2}-\right), 5.98$ (s, 2H, O- $\mathrm{CH}_{2}-\mathrm{O}$ ), 6.43 (d, $1 \mathrm{H}, J=15.1 \mathrm{~Hz}, \mathrm{~N}-\mathrm{CO}-$ $\mathrm{CH}), 6.72-6.99(\mathrm{~m}, 5 \mathrm{H}, \mathrm{Ph}-\mathrm{H}, \mathrm{Ph}-\mathrm{CH}-\mathrm{CH}), 7.35-7.54(1 \mathrm{H}, \mathrm{m}, \mathrm{N}-\mathrm{CO}-\mathrm{CH}-\mathrm{CH})$ These data was in accordance with literature data.[59] Results are based on two independent experiments.

\section{Acknowledgment}

Anna K. Ressmann is a recipient of a DOC-fFORTE-fellowship of the Austrian Academy of Sciences.

[1] D. G. I. Kingston, J. Nat. Prod. 2010, 74, 496-511.

[2] V. G. Gaikar, G. Raman, US6365601B1, 2002.

[3] H. M. D. Navickiene, A. C. Alecio, M. J. Kato, V. S. Bolzani, M. C. M. Young, A. J. Cavalheiro, M. Furlan, Phytochemistry 2000, 55, 621-626.

[4] S. Bajad, K. L. Bedi, A. K. Singla, R. K. Johri, Planta Med. 2001, 67, 284-287.

[5] A. M. Mujumdar, J. M. Dhuley, V. Deshmukh, P. H. Raman, S. R. Naik, Jpn. J. Med. Sci. Biol. 1990, 43, 95-100. 
[6] J. R. Stohr, P. G. Xiao, R. Bauer, J. Ethnopharmacol. 2001, 75, 133-139.

[7] J. Zaugg, I. Baburin, B. Strommer, H.-J. Kim, S. Hering, M. Hamburger, J. Nat. Prod. 2010, 73, 185-191.

[8] S. Hering, T. Erker, T. Schwarz, I. Baburin, D. Schellmann, WO2011080313A1, 2011.

[9] L. Marion, Alkaloids-Chemistry and Physiology (R. H. F. Manske, editor. Academic Press) 1960, 6, 31-34

[10] H. Staudinger, H. Schneider, Ber. Dtsch. Chem. Ges. B 1923, 56B, 699-711.

[11] D. A. Fort, R. C. Remsing, R. P. Swatloski, P. Moyna, G. Moyna, R. D. Rogers, Green Chem. 2007, 9, 63-69.

[12] I. Kilpelaeinen, H. Xie, A. King, M. Granstrom, S. Heikkinen, D. S. Argyropoulos, J. Agric. Food Chem. 2007, 55, 9142-9148.

[13] N. Sun, M. Rahman, Y. Qin, M. L. Maxim, H. Rodriguez, R. D. Rogers, Green Chem. 2009, 11, 646-655.

[14] M. Zavrel, D. Bross, M. Funke, J. Buechs, A. C. Spiess, Bioresour. Technol. 2009, $100,2580-2587$.

[15] A. Brandt, J. P. Hallett, D. J. Leak, R. J. Murphy, T. Welton, Green Chem. 2010, 12, 672-679.

[16] R. P. Swatloski, S. K. Spear, J. D. Holbrey, R. D. Rogers, J. Am. Chem. Soc. 2002, $124,4974-4975$.

[17] A. Pinkert, K. N. Marsh, S. Pang, M. P. Staiger, Chem. Rev. 2009, 109, 6712-6728.

[18] H. Wang, G. Gurau, R. D. Rogers, Chem. Soc. Rev. 2012, 41, 1519-1537. 
[19] S. Zhu, Y. Wu, Q. Chen, Z. Yu, C. Wang, S. Jin, Y. Ding, G. Wu, Green Chem. 2006, $8,325-327$.

[20] Y. Pu, N. Jiang, A. J. Ragauskas, J. Wood Chem. Technol. 2007, 27, 23-33.

[21] H. Xie, S. Zhang, S. Li, Green Chem. 2006, 8, 630-633.

[22] S. Yamazaki, A. Takegawa, Y. Kaneko, J.-i. Kadokawa, M. Yamagata, M. Ishikawa, Electrochem. Commun. 2009, 11, 68-70.

[23] Y. Wu, T. Sasaki, S. Irie, K. Sakurai, Polymer 2008, 49, 2321-2327.

[24] Y. Qin, X. Lu, N. Sun, R. D. Rogers, Green Chem. 2010, 12, 968-971.

[25] D. M. Phillips, L. F. Drummy, D. G. Conrady, D. M. Fox, R. R. Naik, M. O. Stone, P. C. Trulove, L. H. C. De, R. A. Mantz, J. Am. Chem. Soc. 2004, 126, 14350-14351.

[26] H. Xie, S. Li, S. Zhang, Green Chem. 2005, 7, 606-608.

[27] A. Biswas, R. L. Shogren, D. G. Stevenson, J. L. Willett, P. K. Bhowmik, Carbohydr. Polym. 2006, 66, 546-550.

[28] C. He, Q. Wang, J. Sun, X. Chen, CN101225552A, 2008.

[29] H. Garcia, R. Ferreira, M. Petkovic, J. L. Ferguson, M. C. Leitao, H. Q. N. Gunaratne, K. R. Seddon, L. P. N. Rebelo, P. C. Silva, Green Chem. 2010, 12, 367-369.

[30] A. A. Lapkin, P. K. Plucinski, M. Cutler, J. Nat. Prod. 2006, 69, 1653-1664.

[31] A. K. Ressmann, K. Strassl, P. Gaertner, B. Zhao, L. Greiner, K. Bica, Green Chem. 2012, 14, 940-944.

[32] R. Ferreira, H. Garcia, A. F. Sousa, M. Petkovic, P. Lamosa, C. S. R. Freire, A. J. D. Silvestre, L. P. N. Rebelo, C. S. Pereira, New J. Chem. 2012, 36, 2014-2024. 
[33] M. G. Bogdanov, I. Svinyarov, R. Keremedchieva, A. Sidjimov, Sep. Purif. Technol. 2012, 97, 221-227.

[34] M. G. Bogdanov, I. Svinyarov, Sep. Purif. Technol. 2013, 103, 279-288.

[35] H. Zeng, Y. Wang, J. Kong, C. Nie, Y. Yuan, Talanta 2010, 83, 582-590.

[36] C. Yansheng, Z. Zhida, L. Changping, L. Qingshan, Y. Peifang, U. Welz-Biermann, Green Chem. 2011, 13, 666-670.

[37] Y. Xiao, Y. Wang, S. Gao, R. Zhang, R. Ren, N. Li, H. Zhang, J. Chromatogr., B: Anal. Technol. Biomed. Life Sci. 2011, 879, 1833-1838.

[38] K. Bica, P. Gaertner, R. D. Rogers, Green Chem. 2011, 13, 1997-1999.

[39] T. Liu, X. Sui, R. Zhang, L. Yang, Y. Zu, L. Zhang, Y. Zhang, Z. Zhang, J. Chromatogr., A 2011, 1218, 8480-8489.

[40] Y. Zhai, S. Sun, Z. Wang, J. Cheng, Y. Sun, L. Wang, Y. Zhang, H. Zhang, A. Yu, J. Sep. Sci. 2009, 32, 3544-3549.

[41] S. A. Chowdhury, R. Vijayaraghavan, D. R. MacFarlane, Green Chem. 2010, 12 , 1023-1028.

[42] A. K. Ressmann, P. Gaertner, K. Bica, Green Chem. 2011, 13, 1442-1447.

[43] K. Bica, P. Gaertner, P. J. Gritsch, A. K. Ressmann, C. Schroeder, R. Zirbs, Chem. Commun. 2012, 48, 5013-5015.

[44] J. Bowers, C. P. Butts, P. J. Martin, M. C. Vergara-Gutierrez, R. K. Heenan, Langmuir 2004, 20, 2191-2198.

[45] S. Dorbritz, W. Ruth, U. Kragl, Adv. Synth. Catal. 2005, 347, 1273-1279.

[46] Z. Miskolczy, K. Sebok-Nagy, L. Biczok, S. Goektuerk, Chem. Phys. Lett. 2004, 400, 296-300. 
[47] I. Goodchild, L. Collier, S. L. Millar, I. Prokes, J. C. D. Lord, C. P. Butts, J. Bowers, J. R. P. Webster, R. K. Heenan, J. Colloid Interface Sci. 2007, 307, 455-468.

[48] S. P. M. Ventura, L. D. F. Santos, J. A. Saraiva, J. A. P. Coutinho, Green Chem. 2012, $14,1620-1625$.

[49] A. Brandt, M. J. Ray, T. Q. To, D. J. Leak, R. J. Murphy, T. Welton, Green Chem. 2011, 13, 2489-2499.

[50] X. Cao, X. Ye, Y. Lu, Y. Yu, W. Mo, Anal. Chim. Acta 2009, 640, 47-51.

[51] A. F. M. Claudio, A. M. Ferreira, M. G. Freire, J. A. P. Coutinho, Green Chem. 2013, $15,2002-2010$

[52] K. Wu, Q. Zhang, Q. Liu, F. Tang, Y. Long, S. Yao, J. Sep. Sci. 2009, 32, 4220-4226.

[53] X. Lin, Y. Wang, X. Liu, S. Huang, Q. Zeng, Analyst 2012, 137, 4076-4085.

[54] M. Blesic, M. H. Marques, N. V. Plechkova, K. R. Seddon, L. P. N. Rebelo, A. Lopes, Green Chem. 2007, 9, 481-490.

[55] S. O. A. El, P. A. R. Pires, T. Abdel-Moghny, E. L. Bastos, J. Colloid Interface Sci. 2007, 313, 296-304.

[56] J. Luczak, J. Hupka, J. Thoeming, C. Jungnickel, Colloids Surf., A 2008, 329, 125 133.

[57] F. H. Abdel-Salam, A. G. El-Said, J. Surfactants Deterg. 2011, 14, 371-379.

[58] H. Ljusberg-Wahren, D. Lundberg, K. Holmberg, WO2005044237A1, 2005.

[59] P. S.-W. Leung, Y. Teng, P. H. Toy, Org. Lett. 2010, 12, 4996-4999. 
Table 1. Influence of extraction conditions on the extraction yield of piperine from black pepper using a $50 \mathrm{mM}$ solution of $\left[\mathrm{C}_{12} \mathrm{mim}\right] \mathrm{Cl}$ in water.

\begin{tabular}{ccc}
\hline Entry $^{\mathrm{a}}$ & Conditions & Piperine (wt.-\%) \\
\hline 1 & $1 \mathrm{~h}, 5 \mathrm{wt} . \%$ & $3.42 \pm 0.38$ \\
2 & $3 \mathrm{~h}, 5 \mathrm{wt} . \%$ & $3.74 \pm 0.19$ \\
3 & $24 \mathrm{~h}, 5 \mathrm{wt} . \%$ & $4.64 \pm 0.30$ \\
4 & $3 \mathrm{~h}, 1 \mathrm{wt} . \%$ & $3.86 \pm 0.27$ \\
6 & $3 \mathrm{~h}, 5 \mathrm{wt} . \%$ & $3.74 \pm 0.19$ \\
& $3 \mathrm{~h}, 10 \mathrm{wt} . \%$ & $2.93 \pm 0.11$
\end{tabular}

${ }^{a}$ Performed with $50.0 \pm 0.1 \mathrm{mg}$ ground black pepper in $950 \mu \mathrm{L}$ of ionic liquid solution at $25^{\circ} \mathrm{C}$; ' yield was determined via HPLC using phenol as internal standard; ${ }^{\mathrm{c}}$ average of three independent experiments (mean $\pm \mathrm{STD}, n=3$ ). 
Table 2. Influence of different anions on the extraction yield of piperine from black pepper using a $50 \mathrm{~mm}$ solution of $\left[\mathrm{C}_{12} \mathrm{mim}\right] \mathrm{X}$ in water.

\begin{tabular}{ccc}
\hline Entry $^{\mathrm{a}}$ & Ionic liquid solution & ${\text { Piperine }[\mathrm{wt} .-\%]^{\mathrm{b}, \mathrm{c}}}$ \\
\hline 1 & $50 \mathrm{mM}\left[\mathrm{C}_{12} \mathrm{mim}\right] \mathrm{OTf} \mathbf{5}$ & $2.28 \pm 0.19$ \\
3 & $50 \mathrm{mM}\left[\mathrm{C}_{12} \mathrm{mim}\right] \mathrm{Cl} \mathrm{3}$ & $3.74 \pm 0.19$ \\
4 & $50 \mathrm{mM}\left[\mathrm{C}_{12} \operatorname{mim}\right] \mathrm{Br} \mathrm{4}$ & $3.08 \pm 0.13$ \\
5 & $50 \mathrm{mM}\left[\mathrm{C}_{12} \operatorname{mim}\right] \mathrm{N}(\mathrm{CN})_{2} \mathbf{5}$ & $3.28 \pm 0.33$ \\
& $50 \mathrm{mM}\left[\mathrm{C}_{12} \operatorname{mim}\right] \mathrm{OAc} \mathbf{6}$ & $3.35 \pm 0.45$ \\
\hline
\end{tabular}

${ }^{\mathrm{a}}$ Performed with $50.0 \pm 0.1 \mathrm{mg}$ ground black pepper in $950 \mu \mathrm{L}$ of ionic liquid solution at $25{ }^{\circ} \mathrm{C} ;{ }^{b}$ yield was determined via HPLC using phenol as internal standard; ${ }^{\mathrm{c}}$ average of three independent experiments (mean $\pm \operatorname{STD}, n=3$ ). 
Table 3. Extraction efficiencies of pure ionic liquids $\left[\mathrm{C}_{10} \mathrm{mim}\right] \mathrm{Cl},\left[\mathrm{C}_{12} \mathrm{mim}\right] \mathrm{Cl}$ and $\left[\mathrm{C}_{14} \mathrm{mim}\right] \mathrm{Cl}$.

\begin{tabular}{ccc}
\hline Entry $^{\mathrm{a}}$ & Ionic liquid & ${\text { Piperine [wt.-\% }]^{\mathrm{b}, \mathrm{c}}}$ \\
\hline 1 & {$\left[\mathrm{C}_{10} \mathrm{mim}\right] \mathrm{Cl}$} & $3.74 \pm 0.28$ \\
2 & {$\left[\mathrm{C}_{12} \mathrm{mim}\right] \mathrm{Cl}$} & $3.57 \pm 0.28$ \\
3 & {$\left[\mathrm{C}_{14} \mathrm{mim}\right] \mathrm{Cl}$} & $3.52 \pm 0.28$ \\
\hline
\end{tabular}

${ }^{\mathrm{a}}$ Performed with $50.0 \pm 0.1 \mathrm{mg}$ ground black pepper in $950.0 \pm 5.0 \mathrm{mg}$ of pure ionic liquid at $80{ }^{\circ} \mathrm{C} ;{ }^{b}$ yield was determined via HPLC using phenol as internal standard; ${ }^{c}$ average of three independent experiments (mean $\pm \mathrm{STD}, n=3$ ). 


\section{Figure Captions}

Fig. 1. Structures of piperine 1 (left) and ionic liquids 2-9 used in this study (right).

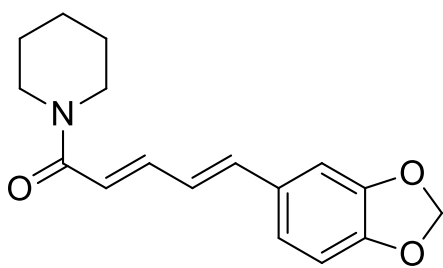

Piperine (1)

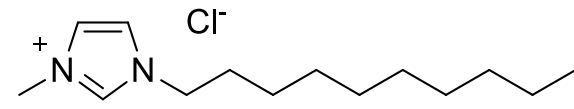

$\left[\mathrm{C}_{10} \mathrm{mim}\right] \mathrm{Cl}(2)$
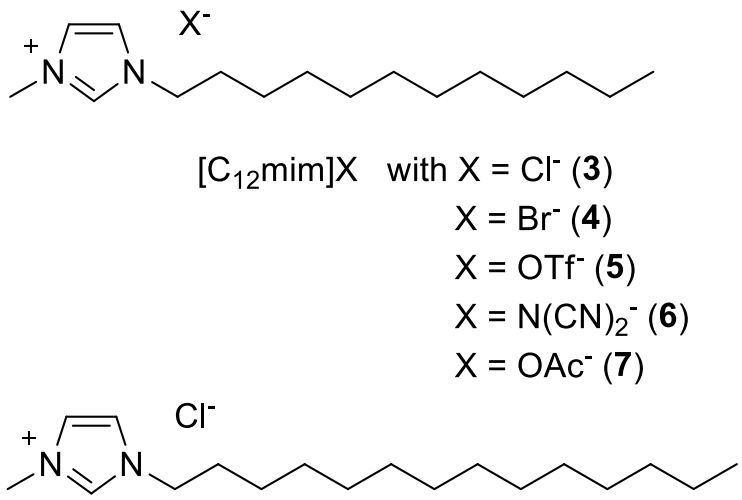

$\left[\mathrm{C}_{14} \mathrm{mim}\right] \mathrm{Cl}(8)$

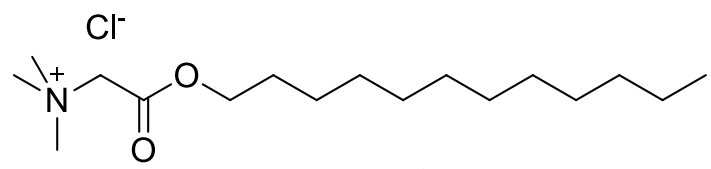

$\left[\mathrm{C}_{12}\right.$ betain $] \mathrm{Cl}(\mathbf{9})$ 
Fig. 2. Influence of the concentration of surface-active ionic liquids in water on the extraction of piperine from black pepper.

\section{Influence of IL concentration}

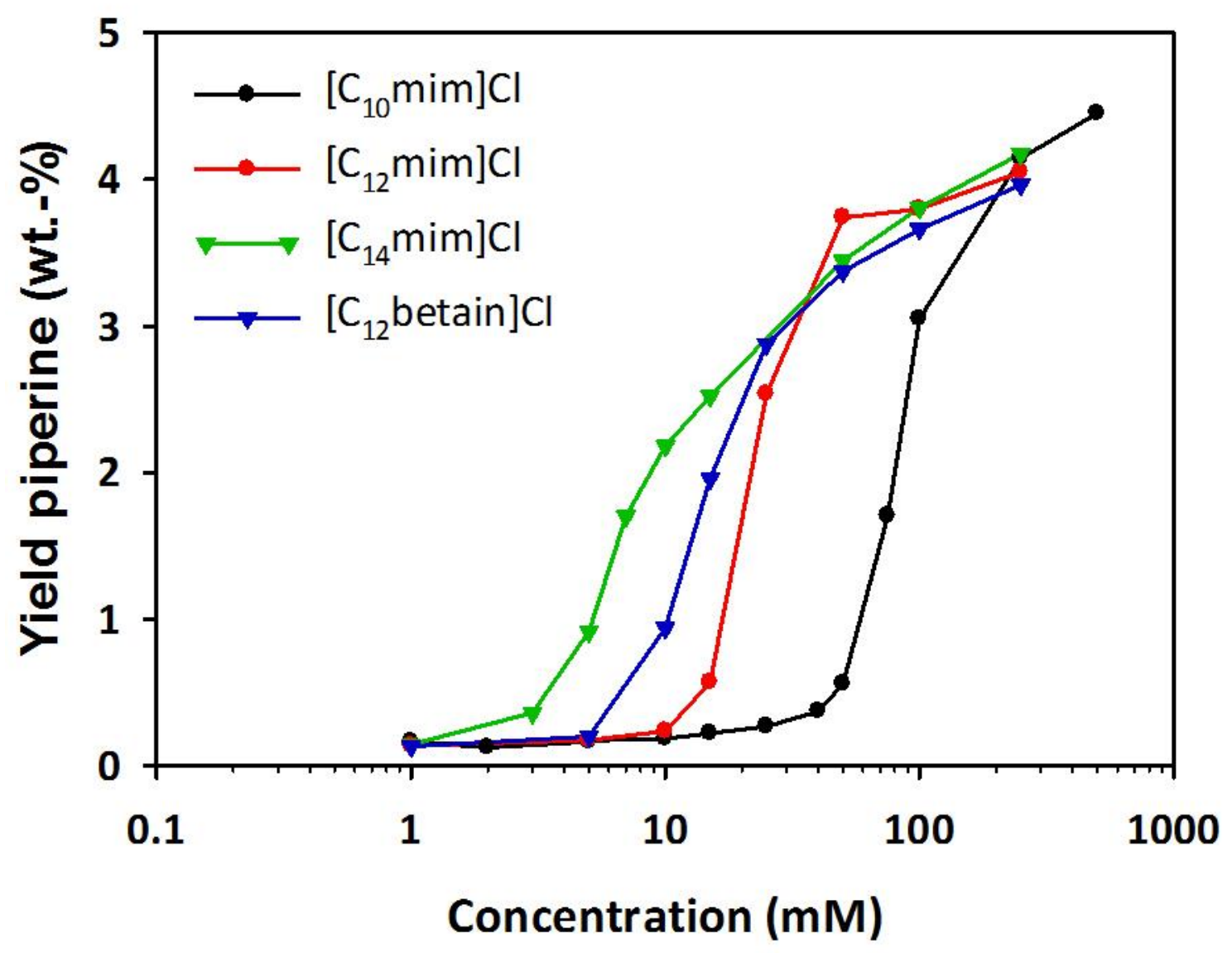


Fig. 3: Comparison of IL and conventional solvents.

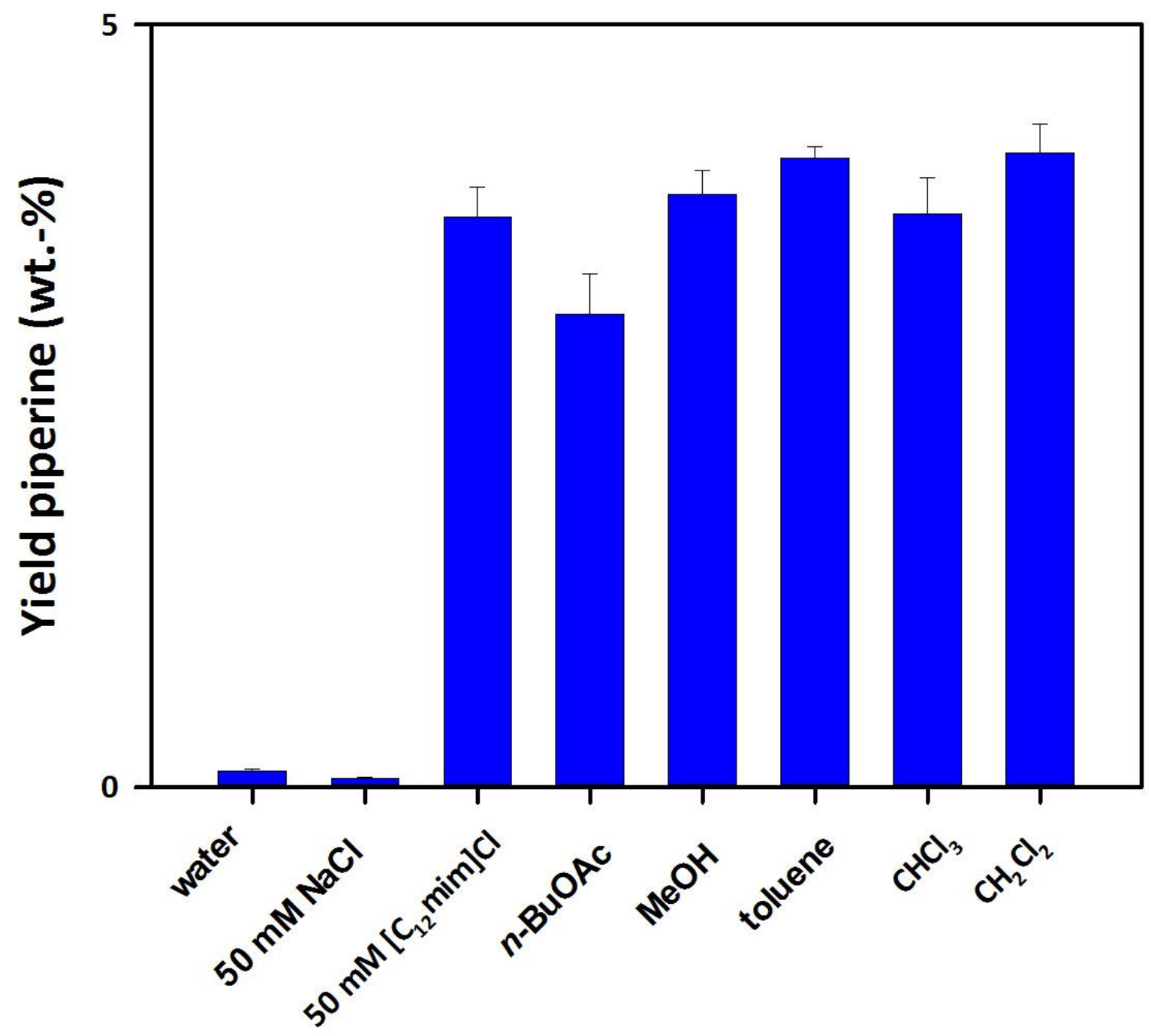


Fig. 4. Electron microscopy of residual pepper after extraction with water (left) and with aqueous ionic liquid micellar solution.
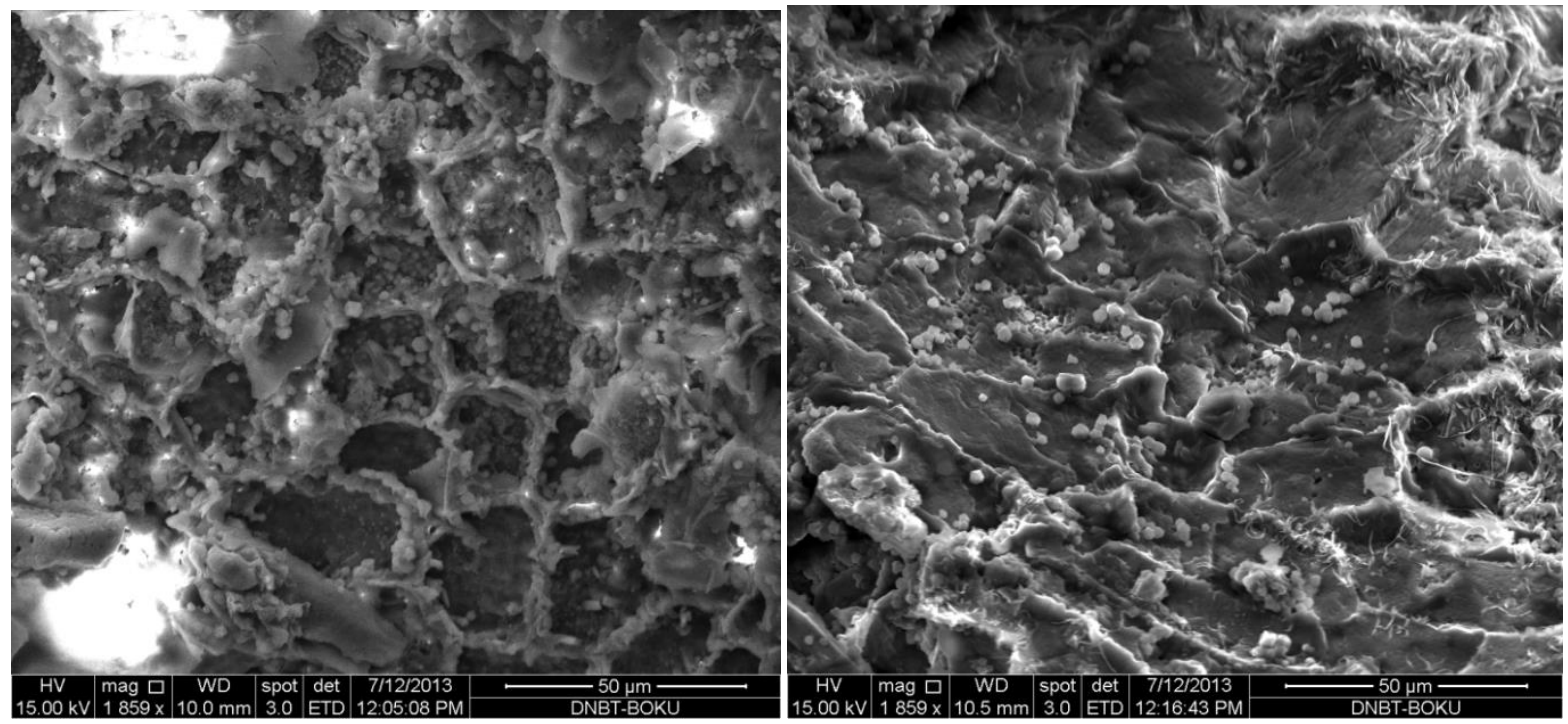
Fig. 5. Scale-up strategy for the isolation of piperine from black pepper.

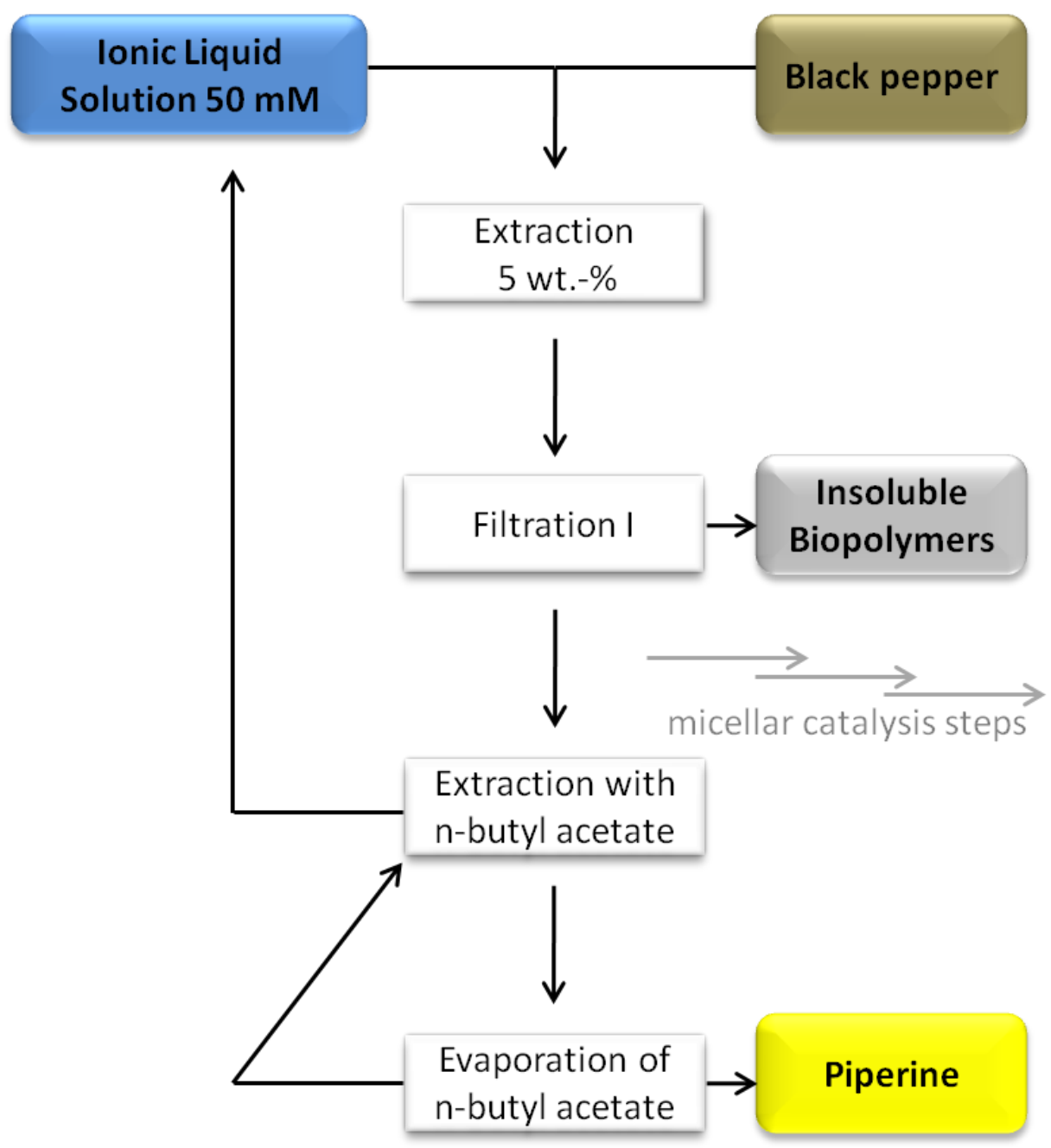


Fig. 6. Results of the scale-up and recycling.

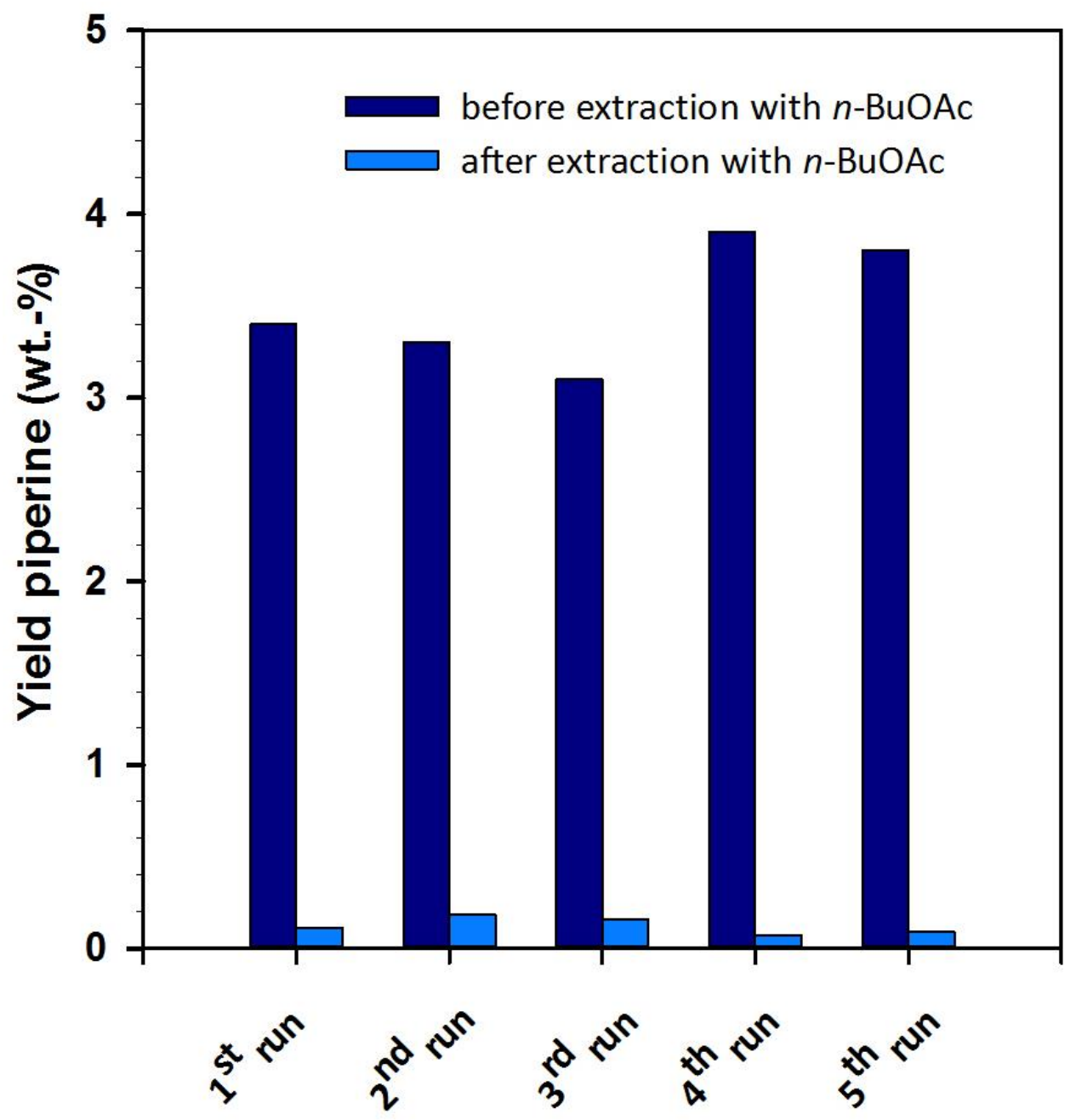

